\title{
PERAN SOCIAL MEDIA TERHADAP ORGANIZATIONAL PERFORMANCE DAN ENTREPRENEURIAL ORIENTATION PADA BISNIS COFFEE SHOP DI JAKARTA BARAT
}

\author{
Polando Polozona Margasho \\ Program Studi Magister Manajemen Universitas Tarumanagara \\ polandopm@gmail.com \\ Eko Harry Susanto \\ Program Studi Magister Manajemen Universitas Tarumanagara
}

Masuk : 30-05-2020, revisi : 25-06-2020 diterima untuk diterbitkan : 25-06-2020

\begin{abstract}
The purpose of this study is to examine the role of social media on organizational performance and entrepreneurial orientation in the coffee shop business in West Jakarta. The sample was chosen using non-probability sampling totaling 50 respondents who are coffee shop business owners who use social media in West Jakarta. Data processing techniques using the SmartPLS 3 program. The results of this study indicate that 1) social media significantly contributes to organizational performance. 2) social media significantly contributes to entrepreneurial orientation.
\end{abstract}

Abstrak : Tujuan dari penelitian ini adalah untuk menguji peran media sosial terhadap kinerja organisasi dan orientasi kewirausahaan pada bisnis kedai kopi di Jakarta Barat. Sampel dipilih menggunakan non-probability sampling berjumlah 50 responden yang merupakan pemilik bisnis kedai kopi yang menggunakan media sosial di Jakarta Barat. Teknik pengolahan data menggunakan program SmartPLS 3. Hasil penelitian ini menunjukkan bahwa 1) media sosial berperan terhadap kinerja organisasi. 2) media sosial berperan terhadap orientasi kewirausahaan.

Keywords : Social Media, Organizational Performance, Entrepreneurial Orientation

\section{PENDAHULUAN}

Perkembangan-perkembangan yang terjadi pada era globalisasi ini banyak sekali membuat perubahan dalam kehidupan, yang terjadi salah satunya yaitu perkembangan teknologi internet, teknologi dalam sebuah media komunikasi dan informasi yang pada saat ini sangat membantu dan memudahkan dalam segala jenis aktivitas yang dilakukan sehari-hari baik yang dilakukan individu maupun yang dilakukan suatu organisasi. Media informasi dan komunikasi tersebut lebih dikenal dengan sebutan 'Social Media'. Social Media bagi entrepreneur dilatar belakangi perubahan teknologi dan perilaku individu, organisasi. Mengubah cara pendekatan seorang entrepreneur dalam bertindak melakukan pemasaran serta menajamenen terhadap usahanya sehingga dapat dikenal lebih detail oleh para konsumen dan kalangan lainnya seperti masyarakat.

Dengan adanya perkembangan yang terjadi, teknologi internet dapat digunakan untuk menghubungkan sebuah jaringan secara online baik individual maupun dalam bentuk organisasi di seluruh dunia. Terdapat enam alasan yang membuat teknologi internet menjadi popular. Alasan tersebut adalah internet memiliki konektivitas dan jangkauan yang luas, dapat mengurangi biaya komunikasi, biaya transaksi, biaya agency, interaktif, fleksibel dan mudah serta memiliki kemampuan untuk mendistribusikan pengetahuan secara tepat (Rofiq, 2007).

Perkembangan social media sebagai suatu alat strategis yang penting di antara organisasi (Gomez Vasquez \& Soto Velez, 2011). Pada tahun 2011, lebih dari 50\% pengguna social media 
mengikuti merek di social media (Belleghem, Eenhuizen, \& Veris, 2011) dan organisasi semakin banyak dalam hal berinvestasi di social media.

Usaha untuk mempunyai stabilitas pada performa bisnis, maka diperlukan adanya suatu entrepreneurial orientation dalam suatu perusahan. Entrepreneurial orientation sudah menjadi hal yang kritis dan mendesak bagi perusahaan yang menghadapi persaingan dan tekanan dalam pasar yang terus meningkat (Slater \& Naver, 1995;65). Social Media telah mengubah cara pandang dalam melakukan bisnis, memungkinkan komunikasi yang terbuka yang membantu organisasi untuk memahami kebutuhan pelanggan dan juga memotivasi organisasi untuk proaktif dalam menanggapi kebutuhan pelanggan dengan cara yang efisien.

Tingkat konsumsi kopi di Indonesia meningkat dari tahun ke tahun, seperti data yang diperoleh bahwa pada tahun 2010 konsumsi kopi sebesar 3,5 juta, 2012 konsumsi kopi sebesar 4 juta, 2015 konsumsi kopi sebesar 4,5 juta, 2016 konsumsi kopi sebesar 4,7 juta (databoks.co.id).

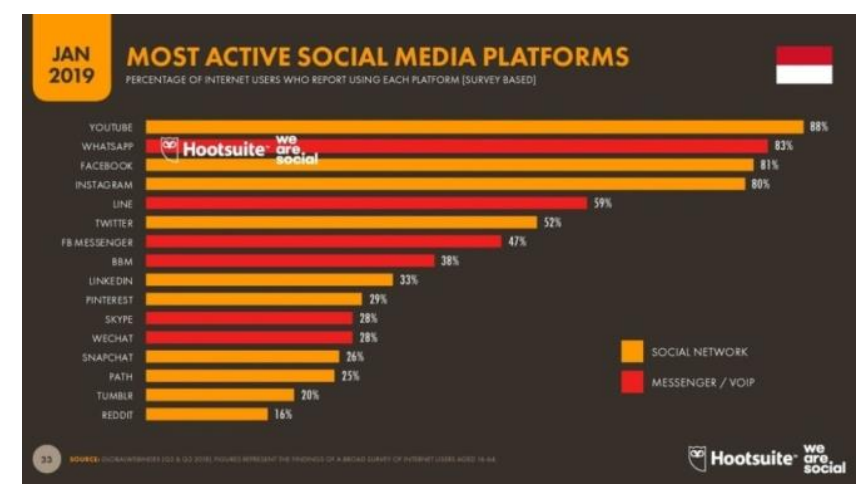

Gambar 1

Aplikasi Media Sosial yang paling banyak digunakan di Indonesia

\section{TINJAUAN PUSTAKA}

Menurut Gonzalez dan Wang (2016:96) (sebagaimana dikutip dari Susanto 2018:50), jaringan komunikasi menawarkan satu jalan untuk saling bergantung, menciptakan ikatan diantara orang-orang yang ada di dalamnya melalui teknologi digital, kecepatan komunikasi dalam membangun pemahaman bersama untuk melakukan tindakan kolektif. Termasuk dalam kategori new media, media sosial yang didukung teknologi komunikasi, antara lain berbentuk: forum internet, weblog, blog sosial, microblogging, wiki, podcast, foto atau gambar, video, dan perangkat lain dalam penggunaan informasi (Kaplan \& Haenlein, 2010:62) (sebagaimana dikutip dari Susanto 2018:50). Media sosial juga memberikan layanan dalam interaksi melalui teknologi dengan media internet disebut interactive media (Burke, 2000:380) (sebagaimana dikutip dari Susanto 2018:50).

Menurut Hamon (2003) bahwa performa organisasi adalah indikator yang dapat digunakan untuk mengukur pencapaian tujuan suatu usaha. Tomal \& Jones (2015) mendefinisikan performa organisasi sebagai hasil aktual atau output dari suatu organisasi yang diukur terhadap output yang dimaksudkan oleh organisasi.

Menurut Jin-Nan dkk. (2011) terdapat langkah-langkah performa organisasi pada empat dimensi yaitu peningkatan penjualan, penurunan biaya logistik, meningkatkan produktivitas staf, dan meningkatkan layanan pelanggan. Menurut Zack dkk. (2009) terdapat langkahlangkah performa organisasi pada lima dimensi yaitu inovasi, laju pengembangan produk baru, kepuasan pelanggan, retensi pelanggan, dan biaya operasi.

Messeghem (2003) mengartikan orientasi kewirausahaan sebagai suatu kemampuan perusahaan dalam melihat peluang usaha yang baru. Dalam hal ini, Messeghem menyebut lima indikator dalam orientasi kewirausahaan yaitu standarisasi, formalisasi, spesialisasi, sistem perencanaan dan pengendalian, sistem informasi eksternal. Ginsberg (2011), mendefinisikan 
orientasi kewirausahaan sebagai kecenderungan tiap individu untuk melakukan inovasi, proaktif, dan mau mengambil risiko dalam usaha.

Menurut Kasali (2010), bahwa inovasi adalah kemampuan untuk melihat segala sesuatu dengan menggunakan cara yang baru dan belum pernah ada di pasar, dan kadang di luar kebiasaan. Tindakan proaktif adalah mencari kesempatan baru yang mungkin berhubungan ataupun yang tidak berhubungan dengan lini operasi saat ini. Keberanian mengambil risiko adalah tingkat kesediaan untuk berkomitmen terhadap sumber daya yang berisiko dan jumlahnya besar.

Reaksi dan persepsi terhadap pengguna yang menggunakan Teknologi Informasi (TI) dapat mempengaruhi sikap dalam penerimaan informasi terhadap teknologi. Salah satu faktor yang dapat mempengaruhi yaitu persepsi pengguna mengenai manfaat dan persepsi yang didapatkan mengenai kemudahan menggunakan TI sebagai suatu tindakan yang beralasan dalam konteks pengguna teknologi.

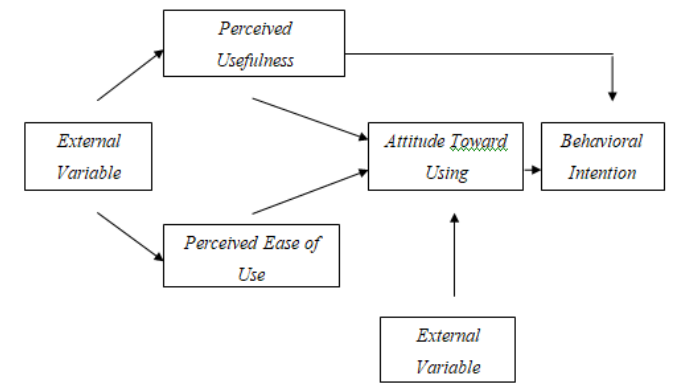

\section{Gambar 2}

Theory - Technology Acceptance Model

Selain menggunakan teori TAM, terdapat teori lain yang dapat mendasari penulis dalam penelitian ini yaitu theory of planned behavior (TPB), yang merupakan model yang diperluas dari TRA. Dalam TRA dijelaskan bahwa niat seseorang terhadap perilaku dibentuk oleh dua faktor utama yaitu attitude toward the behavior dan subjective norms (Fishbein \& Ajzen, 1975), sedangkan dalam TPB ditambahkan satu faktor lagi yaitu perceived behavioral control (Ajzen, 1991).

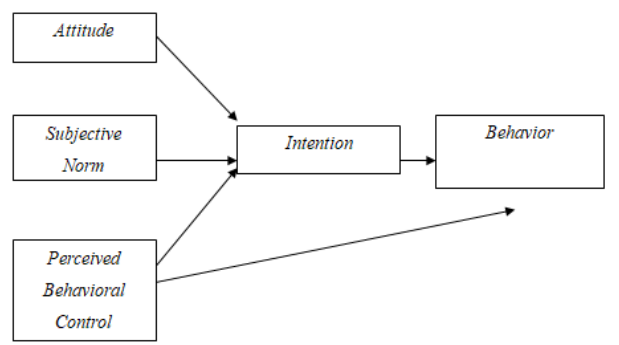

\section{Gambar 3}

\section{Kerangka Pemikiran}

\section{Model Theory of Planned Behavior}

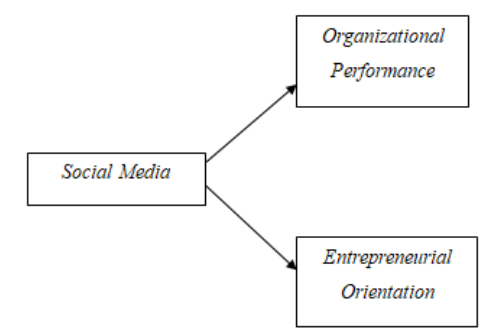

\section{Hipotesis Penelitian}

H1 : Social media usage merupakan prediktor yang positif atas organizational performance pada bisnis coffee shop di Jakarta Barat.

$\mathrm{H} 2$ : Social media usage merupakan prediktor yang positif atas influences the entrepreneurial orientation of an organization pada bisnis coffee shop di Jakarta Barat. 


\section{METODOLOGI PENELITIAN}

Dalam penelitian ini menggunakan data primer dengan menyebarkan kuesioner kepada responden secara langsung melalui googleform. Penelitian ini menggunakan dua variabel yaitu variabel independen dan variabel dependen. Variabel independen yang digunakan yaitu Social Media. Kemudian variabel dependen yang digunakan yaitu Organizational Performance dan Entrepreneurial Orientation Peneliti menggunakan metode nonprobability sampling dengan jumlah kuesioner yang disebarkan sebanyak 50 responden. Dasar penetapan sampel yaitu Coffee Shop yang menggunakan media sosial dalam kegiatan usahanya, serta jangka waktu penelitian, keterbatasan jumlah coffee shop di Jakarta Barat dan penelitian ini disebarkan dengan cara mendatangi langsung pada Coffee Shop. Menurut Supranto (2003), jumlah sampel sebanyak 30 responden merupakan persyaratan minimal dalam suatu penelitian. Adapun metode analisis data yang digunakan dalam menguji Hipotesis Statistik dan Pengujiannya menggunakan uji R-Square $\left(\mathrm{R}^{2}\right)$, uji F-Square $\left(\mathrm{F}^{2}\right), \mathrm{Q}-$ Square $\left(\mathrm{Q}^{2}\right)$, uji GoF (Goodness of Fit), pengujian signifikansi dengan Metode Boostrap.

HASIL \& KESIMPULAN

1. Uji R-Square $\left(\mathbf{R}^{2}\right)$

Tabel 1

Hasil R-Square

\begin{tabular}{|c|c|}
\hline & R-Square \\
\hline EO & 0,783 \\
\hline OP & 0,682 \\
\hline
\end{tabular}

a) Social Media terhadap Entrepreneurial Orientation

Dari tabel 1 dapat diketahui bahwa social media memiliki prediksi yang kuat sebesar 0,783 terhadap entrepreneurial orientation yang artinya apabila terjadi perubahan pada variabel social media, maka entrepreneurial orientation juga akan mengalami perubahan sebesar 78,3\% dan sisanya sebesar $21,7 \%(100 \%-78,3 \%)$ adalah efek dari faktor diluar struktur ini.

b) Social Media terhadap Organizational Performance

Dari tabel 1 dapat diketahui bahwa social media memiliki prediksi yang kuat sebesar 0,682 terhadap organizational performance yang artinya apabila terjadi perubahan pada variabel social media, maka organizational performance juga akan mengalami perubahan sebesar 68,2\% dan sisanya sebesar 31,8\% (100\%-68,2\%) adalah efek dari faktor diluar struktur ini.

2. Uji F-Square $\left(\mathbf{F}^{2}\right)$

Tabel 2

Hasil F-Square

\begin{tabular}{|c|c|c|c|}
\hline & EO & OP & SM \\
\hline EO & & & \\
\hline OP & & & \\
\hline SM & 3,612 & 2,144 & \\
\hline
\end{tabular}

a) Ukuran efek social media terhadap entrepreneurial orientation

Dari tabel 2, dapat disimpulkan bahwa variabel social media memiliki dampak yang besar pada nilai F-Square variabel entrepreneurial orientation sebesar 3,612.

b) Ukuran efek social media terhadap organizational performance

Dari tabel 4.2, dapat disimpulkan bahwa variabel social media memiliki dampak yang besar pada nilai F-Square variabel organizational performance sebesar 2,144.

3. Uji Q-Square $\left(\mathbf{Q}^{2}\right)$

Tabel 3

Hasil Q-Square

\begin{tabular}{|c|c|c|c|c|}
\hline & SSO & SSE & $\mathrm{Q}^{2}(=1-\mathrm{SSE} / \mathrm{SSO})$ & \\
\hline EO & 450.000 & 248.514 & 0,448 & Besar \\
\hline OP & 450.000 & 300.273 & 0,333 & Besar \\
\hline
\end{tabular}




\section{\begin{tabular}{l|r|r} 
SM & 450.000 & 450.000
\end{tabular}}

Nilai $\left(\mathrm{Q}^{2}\right)$ lebih besar dari 0 (nol) menunjukkan bahwa nilai-nilai yang diobservasi sudah direkontruksi dengan baik. Sehingga dapat disimpulkan bahwa semua variabel memiliki relevansi prediktif dan memiliki pengaruh besar.

4. Goodness of Fit Model (GoF)

Tabel 4

Hasil AVE

\begin{tabular}{|c|c|}
\hline Variabel & Average Variances Exctracted (AVE) \\
\hline EO & 0,620 \\
\hline OP & 0,588 \\
\hline SM & 0,643 \\
\hline
\end{tabular}

Setelah nilai rata-rata $A V E$ dan $\mathrm{R}$-square yang diperlukan telah didapat, maka dapat dihitung besarnya GoF dengan menggunakan rumus berikut:

$$
\begin{aligned}
\text { GoF: } & \sqrt{\overline{A V E} \times \overline{R^{2}}} \\
& : \sqrt{0,617 \times 0,783} \\
& : \mathbf{0 , 6 9 5}(\mathbf{E O}) \\
\text { GoF: } & \sqrt{\overline{A V E} \times \overline{R^{2}}} \\
& : \sqrt{0,617 \times 0,682} \\
& : \mathbf{0 , 6 4 8}(\mathbf{O P})
\end{aligned}
$$

\section{Pengujian Hipotesis Dengan Menggunakan Metode Bootstrapping}

\section{Tabel 5}

Hasil Bootstraping

\begin{tabular}{|c|c|c|c|c|c|}
\hline & $\begin{array}{c}\text { Original Sample } \\
(\mathrm{O})\end{array}$ & $\begin{array}{c}\text { Sample Mean } \\
(\mathrm{M})\end{array}$ & $\begin{array}{c}\text { Standard Deviation } \\
(\text { STDEV) }\end{array}$ & $\begin{array}{c}\mathrm{T} \\
\text { Statistics }\end{array}$ & $\begin{array}{c}\mathrm{P} \\
\text { Values }\end{array}$ \\
\hline $\mathrm{SM} \rightarrow \mathrm{EO}$ & 0,885 & 0,893 & 0,037 & 23,923 & 0,000 \\
\hline $\mathrm{SM} \rightarrow \mathrm{OP}$ & 0,826 & 0,847 & 0,041 & 20,368 & 0,000 \\
\hline
\end{tabular}

Dari hasil pengujian signifikansi output bootstrapping, maka dapat dijelaskan hipotesis sebagai berikut :

a) Hasil pengujian variabel social media terhadap organizational performance memiliki nilai T-Statistics sebesar 20,368, maka H1 tidak ditolak karena T-Statistics lebih besar dari T-Value 1,96. Artinya, social media merupakan prediktor yang positif atas organizational performance pada pemilik bisnis coffee shop di Jakarta Barat.

b) Hasil pengujian variabel social media terhadap entrepreneurial orientation memiliki nilai T-Statistics sebesar 23,923, maka $\mathrm{H} 2$ tidak ditolak karena T-Statistics lebih besar dari T-Value 1,96. Artinya, social media merupakan prediktor yang positif atas entrepreneurial orientation pada pemilik bisnis coffee shop di Jakarta Barat.

\section{KESIMPULAN}

Social media sebagai faktor penentu yang merupakan prediktor atas organizational performance (Paridon \& Carraher, 2009; Parveen 2014). Social media penting dalam mempengaruhi performa organisasi. Jika organisasi menggunakan social media secara efektif untuk berbagai tugas seperti pemasaran, hubungan pelanggan, dan pencarian informasi (Parveen et al., 2014). Oleh sebab itu, peneliti menyimpulkan bahwa semakin tinggi persepsi social media terhadap suatu organisasi, semakin tinggi juga performa suatu organisasi tersebut.

Social media juga diajukan sebagai faktor penentu yang merupakan prediktor atas entrepreneurial orientation, jika organisasi menggunakan social media, memungkinkan organisasi untuk terlibat dalam komunikasi terbuka dengan pelanggan tentang citra atau merek yang dipersepsikan dan citra mereka sebagai pemimpin inovatif dan pasar, mendapat masukan dari pelanggan dan informasi pesaing tentang produk dan layanan yang memungkinkan untuk bertindak secara proactively dalam memecahkan masalah dan meningkatkan layanan, serta risk-taking yang berarti siap untuk mengambil risiko yang dihadapi terhadap perubahan metode marketing dari tradisional menjadi modern (Brown \& Duguid, 2000; Cairncross, 2001; Zyl, 
2009; Akar \& Topcu, 2011). Oleh sebab itu, peneliti menyimpulkan bahwa semakin tinggi persepsi social media terhadap orientasi kewirausahaan dalam suatu organisasi, semakin tinggi juga tingkat orientasi kewirausahaan dalam suatu organisasi tersebut.

\section{Saran}

Pada penelitian ini sampel yang digunakan untuk diteliti hanya menggunakan sampel di wilayah Jakarta Barat saja, penelitian selanjutnya dapat berfokus pada wilayah lainnya yang lebih luas, seperti Jakarta Utara, Jakarta Timur, Jakarta Selatan, Jakarta Pusat, ataupun wilayah lainnya diluar Jakarta untuk dapat melihat hasil dari penelitian yang bervariasi.

Pada penelitian ini masih berkonsentrasi pada bisnis coffee shop saja, maka penelitian selanjutnya dapat melakukan penelitian pada bisnis usaha yang lain untuk dapat dijadikan sebuah perbandingan dengan penelitian ini. Variabel penelitian ini yaitu social media, organizational performance, entrepreneurial orientation, penelitian selanjutnya dapat menambahkan variabel-variabel lain yang masih dapat berkaitan dengan variabel ini, yang dapat berguna sebagai perbandingan dengan penelitian ini.

Pada bisnis coffee shop pentingnya untuk dapat meningkatkan penggunaan manfaat dari penggunaan social media yang diharapkan dapat meningkatkan organizational performance dan entrepreneurial orientation yang dimiliki. Jika hal seperti itu dilakukan, akan sangat menguntungkan bagi pemilik bisnis karena dapat meningkatkan keuntungan. Namun penggunaan social media harus dilakukan dengan efektif dan efisien, seperti untuk marketing, customer relations \& service, information accessibility. Pada organizational performance harus mengetahui tentang impact on cost reduction, improved customer relations \& service, enhanced information accessibility. Pada entrepreneurial orientation akan lebih baik harus mengetahui dan memiliki, proactiveness, risk taking, innovativeness.

\section{DAFTAR PUSTAKA}

Gomez Vasquez, L. M. and Soto Velez, I. (2011). Social Media as A Strategic Tool for Corporate Communicationcov-Los Medios Sociales Como Una Herramienta Estratégica Para La Comunicación Corporativa. Revista Internacional de Relaciones Públicas, 1 (2 (jul-dic)), 157-174.

Hamon, T. T. (2003). Organizational Effectiveness as Explained by Social Structure in a FaithBased Business Network Organization. Regent University, Virginia Beach, VA.

Jin-Nan, Wu. (2011). Application Capability of e-Business, e-Business Success, and Organizational Performance : Empirical Evidence from China.

Kasali, Rhenald, (2010). Wirausaha Muda Mandiri. Jakarta : Gramedia Pustaka Utama.

Messeghem, K. (2003). Strategic Entrepreneurship and Managerial Activities in SMEs. International Small Business Journal, 21 (2), 197-212.

Rofiq, Ainur. (2007). Pengaruh Dimensi Kepercayaan (Trust) terhadap Partisipasi Pelanggan E-Commerce (Studi pada pelanggan E-Commerce di Indonesia). Program Studi Manajemen, Program Pascasarjana Fakultas Ekonomi Universitas Brawijaya Malang.

Slater, Stanley, \& Narver, John. (1995). Market Orientation and the Learning Organization. Journal of Marketing, 59, 63-74.

Susanto, E.H. (2018). Komunikasi Manusia, Teori dan Praktek dalam Penyampaian Gagasan.

Tomal, D.R. \& Jones, K.J. (2015). A Comparison of Core Competencies of Women and Men Leaders in the Manufacturing Industry. The Coastal Business Journal, 14, 13-25.

Van Belleghem, Steven, Marloes Eenhuizen, \& Elias Veris. (2011). Social Media Around the World 2011.

Zack, Michael, et al. (2009). Knowledge Management and Organizational Performance : An Exploratory Analysis. Journal of Knowledge Management, 13 (6), 392-409. Q Emerald Group Publishing.

www.databoks.co.id. Konsumsi Kopi Indonesia.

www.hootsuite.com. Most Active Social Media Platforms. 